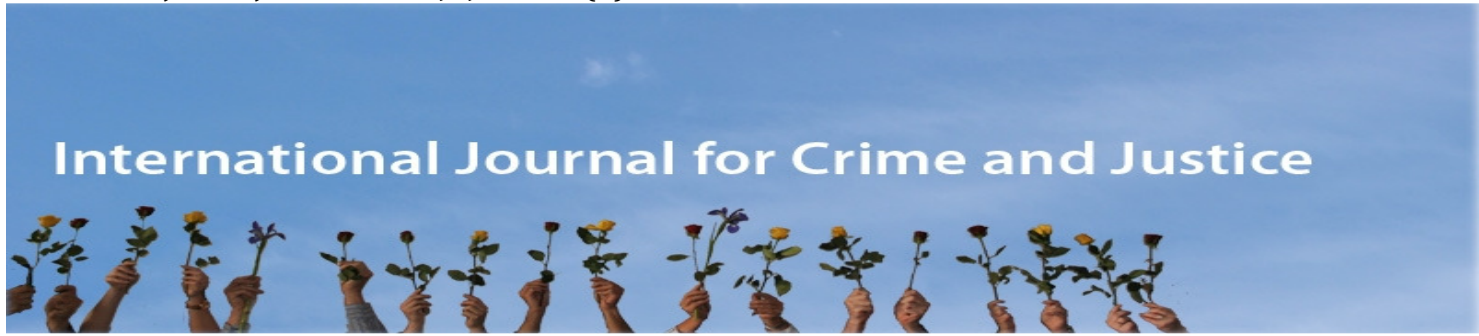

\title{
Identity, Forgiveness and Power in the Management of Child Sexual Abuse by Personnel in Christian Institutions
}

\section{Jodi Death}

Queensland University of Technology

\begin{abstract}
The ongoing crises of child sexual abuse by Christian institutions leaders across the Anglophone world continue to attract public attention and public inquiries. The pervasiveness of this issue lends credence to the argument that the prevailing ethos functioning within some Christian Institutions is one which exercises influence to repeatedly mismanage allegations of child sexual abuse by Church leaders. This work draws on semistructured interviews conducted with 15 Personnel in Christian Institutions (PICIs) in Australia who were identified as being pro-active in their approach to addressing child sexual abuse by PICIs. From these data, themes of power and forgiveness are explored through a Foucaultian conceptualising of pastoral power and 'truth' construction. Forgiveness is viewed as a discourse which can have the power effect of either silencing or empowering victim/survivors. The study concludes that individual PICIs' understandings of the role of power in their praxis influences outcomes from the deployment of forgiveness.
\end{abstract}

\section{Key words}

Child sexual abuse, clergy, identity, forgiveness, pastoral power.

\section{Introduction}

Despite significant study over the last several decades, there continues to be room for analyses of the crises of child sexual abuse by Personnel functioning at a number of levels within Christian institutions. This includes increasing understanding of forms of institutional management of criminal behaviour and the ways in which 'employees' and employers may be criminalised. Similarly, there is significant contention around the legal liability of individuals such as a Pope for allegedly mismanaging and engaging in cover-ups of reports of child abuse by Church leaders (Robertson 2010). This is an intricate and multi-layered problem that has been tested in a range of public, legal and academic forums. 
This paper addresses the use of forgiveness as an institutional discourse, commencing with a brief exploration of the theoretical context for this study, drawn from Foucault's works on power and discourse. The primary data for this piece comes from a study where 15 Personnel in Church Institutions (PICIs) who were identified as having a pro-active intent in their experiences of managing abuse by other PICIs were interviewed. The term 'Personnel in Church Institutions' is used here in recognition that it is not only ordained members of Christian intuitions that abuse children sexually. Unfortunately, space here does not allow for a detailed analysis of all participants' voices and so this paper reflects the voices of participants who most clearly, articulately and concisely discussed concepts of forgiveness, identity and power. Of central concern is how individuals, as PICIs, understand the utility of discourses of forgiveness in the management of abuse by PICIs.

\section{Background to child sexual abuse in Religious Institutions}

Although now faced with decades of criticism over management of child sexual abuse (hereafter abuse) by PICIs, Christian institutions are not alone in criticisms that victims of abuse have not been made visible or had their needs adequately recognised. Outside of Christian institutions there is a long social, political and legal history of victims of abuse being marginalised, unrecognised and subjected to silencing discourses in criminal justice systems (Daly 2011). Victims of sexual violence have long struggled to be recognised as legitimate subjects in legislation, in courtrooms and in public discourse (Carrington and Carmody 2000; Smart 1995; Young 1998). Arguably, although perhaps less so, this is still the case in many circumstances and hence alternative interventions in cases of abuse have been considered from a number of perspectives (Cossins 2008). Further, there continues to be effort directed at building systems that meet the needs of victims of sexual violence and childhood abuse, as well as balancing evidentiary needs in criminal justice adjudication.

Smart (1989) provided one of the first clear articulations of ways in which rape victims' narratives were co-opted and silenced through traditional criminal justice processes and legal constructs of 'truth'. Smart (1989) critiqued criminal justice systems as phallocentric and unable to conceptualise sexual violence in ways that enabled recognition of victims. Further, and differing, critiques of the ways in which sexual violence is policed and prosecuted have been offered by a number of Feminist scholars who have emphasised the neglect and abuse of victims, their rights and their stories (Brownmiller 1975; Carrington and Watson 1996; Walklate 2008). These critiques confronted, amongst other issues, the silencing function of criminal justice systems through Police interviews that were experienced by victims as interrogations; re-traumatisation and humiliation of victims who gave evidence in court; and high attrition rates of cases of sexual violence (Chambers and Millar 1987; Department for Women 1996). Beyond this, broader social constructions of sexual violence which created cultures of shame, embarrassment and fear for victims were, and continue to be, substantially critiqued from Feminist perspectives (Carmody 1997; Esteal 1994; Rowntree 2010). Whilst some advances have been made in the treatment and recognition of victims of sexual violence in criminal justice systems, evidence suggests that there continues to be serious deficiencies in this area (Walklate 2012). Interestingly, many of these techniques of silencing and marginalising victims of sexual violence have been reported by victims who have pursued complaints of Church abuse within Church processes (Death 2012; Keenan 2012).

Crises of abuse within Christian institutions and shifting social and political demands for proactive intervention have often been the trigger for the creation of denominational child protection policies, Church leader education programs and education of Church members. In reality, Christian institutions have historically responded to the occurrence of abuse by leaders within Church institutions and well-documented practices of abuse date back centuries (cf. Dale and Alpert 2007). Responses of the modern Christian institutions have included secrecy, denial, victim blaming, treatment of offenders, the silencing of victim/survivors ${ }^{1}$ and at times the 
support of victim/survivors, their families and a careful and caring response to their needs. In some instances, PICIs accused of abuse have been subjected to defrocking, excommunication, or life confinement to monasteries; or have been handed over to secular authorities who have sometimes fined, castrated or beheaded offenders (Dale and Alpert 2007: 61).

Enquiries into mismanagement of allegations of abuse have mostly been targeted at Roman Catholic and Anglican denominations. Such inquiries have been undertaken in Australia, Ireland, the United States of America and within the United Kingdom (Department of Justice and Equality 2009; John Jay College of Criminal Justice 2004; Keenan 2012). In all such jurisdictions where enquiries have occurred, similar results have been found. Enquiries have often been instigated due to intense political and social lobbying by victims' advocates whose central arguments have been that Christian institutions act to the great detriment of Church abuse victims in that they cannot be trusted to manage cases of abuse by PICIs; do not cooperate with 'secular authorities'; often revictimise and retraumatise through their management of allegations and substantiations; do not take adequate action against abusive PICIs; and will not openly acknowledge that issues of abuse exist (Balboni 2011; Keenan 2012). Further criticisms include the mishandling of abuse substantiations through silence clauses added to settlements with victims; inadequate intervention provided to protect others from becoming victims of known perpetrators; and perceptions that Churches are more concerned about reputation and finances than victims and their families. Where such enquiries have taken place, they have repeatedly recognised a failure to protect children; the occurrence of significant abuse; and the mismanagement of allegations and substantiations by the Christian institutions being scrutinised (Balboni 2011; Keenan 2012). In the Australian context, an enquiry investigating criminal abuse in religious organisations is currently underway in the state of Victoria and, moreover, a Royal Commission into child sexual abuse in institutions was announced by the Federal Government in November 2012 (Cannon 2012; Cullen 2012; Jenkins and Iaria 2012). Hearings commenced in April 2013 but the Royal Commission's report is not expected before the end of 2015.

It is increasingly recognised that institutional structures of Christian institutions deeply inform the responses of denominations to the occurrence and report of abuse by PICIs (Franz 2002: 6). This is not unlike other criminal justice, social and political institutions (cf. White and Terry 2008). What is significant in Christian institutions is that institutional structure, leadership and the capacity to respond to reports of abuse are informed by closely held theological traditions and discourses. Such discourses often value forgiveness as a defining characteristic of a 'Christian' response (cf. Franz 2002). It is in understanding the role of forgiveness in Church responses to abuse by Church leaders that there exists a need for further empirical study. This work seeks to address something of that gap.

Understanding the role of Church ethos and its transmission in addressing abuse by PICIs is an important step forward in creating spaces where the needs of victim/survivors, Church members, offending leadership and non-offending leadership can be met consistently, justly and with integrity and compassion. Central to this is an understanding of PICIs, particularly ordained PICIs, as producers of knowledge and the exercise of power inherent in this function. Foucault's (cf. 1976, 1980) work on power/knowledge and confession has much to offer in understanding the role of ordained leaders in managing instances of abuse in Christian institutions, including responding to victim/survivors. Butler's (cf. 2006, 2005) conceptualisation of the narrative construction and presentation of self and other also can offer insights into the means of identity formation extended to victim/survivors of abuse by personnel within the institutional ethos. It is here that the idea of 'confessions' of self, or constructing identity, can be explored in the context of forgiveness and the management of abuse by PICIs. 


\section{Foucault, power and technologies of self}

Foucault's work includes an interest in religious organisms, in particular Christianity, as systems of power which seek to govern and construct the religious subject (Carrette 1999: 25). Foucault's (cf. 1985, 1986) interest in Christianity and sexuality led him to consider confession as a technology of the self and as a means of extending discourses of sexuality within Christianity. For Foucault (1976: 61), confession can be understood as a part of governmentality where the Church, or rather Church leaders, exercise pastoral powers and the 'other' becomes known in relation to networks of power/knowledge.

Foucault (1994: 333) was particular in outlining a concept of pastoral power which he describes as a 'very special form of power' reliant on four primary principles:

1. It is a form of power whose ultimate aim is to assure individual salvation in the next world

2. Pastoral power is not merely a form of power that commands; it must also be prepared to sacrifice itself for the life and salvation of the flock. Therefore, it is different from royal power, which demands a sacrifice from its subjects to save the throne.

3. It is a form of power that looks after not just the whole community but each individual in particular during his entire life.

4. Finally, this form of power cannot be exercised without knowledge of the inside of people's minds, without exploring their souls, without making them reveal their innermost secrets. It implies a knowledge of the conscience and an ability to direct it.

This form of power presents a complex relationship for victim/survivors of abuse by PICIs who continue to seek the guidance, comfort and spiritual direction of non-offending PICIs. In such circumstances, victim/survivors continue to be governed by individuals who are working within the very same discourses of power that those who have abused them utilised to perpetrate abuse and silence victim/survivors. This may be similar to abuse in other institutions where those suffering the violence must appeal to the peers of perpetrators for redress (Gadon, Johnston and Cooke 2006). Foucault's (1994: 333) further point on pastoral power, however, is that it is 'linked with a production of truth - the truth of the individual'. This understanding recognises complex relationships and subjectivities of victim/survivors of abuse within pastoral relationships. In this way, the role of PICI in identity production, through truth production, becomes a significant element for victim/survivors to contend with. This is so not only for constructing identity of victim/survivors but also for constructing identity of perpetrators.

Whilst forgiveness discourse such as reconciliation and apology are not absent from public and political discourse, in the Christian institutions it has historically played a significant role in the construction of Christian identity and the governance of others (cf. Oliner 2009; Shults and Sandgate 2003). In relation to the role of forgiveness in responses to abuse by PICIs, it has been recognised that forgiveness has functioned to silence victim/survivors, deny them voice and marginalise their stories (cf. Franz 2002). Such discourses of forgiveness include widely recognised concepts such as 'forgive and forget' and also more Church-specific concepts of unconditional forgiveness and grace (cf. Franz 2002; Parkinson 2003). As Foucault (1976: 6162) argues, forgiveness is an intrinsic part of Christian faith which, in the sense it is utilised in testimonies of self, is a confessional practice that acts as a technology of self and occurs within power relationships. This technology of self is worked out and exercised by the subject in communion with others, largely with those who hold an authority to engage in a pastoral discursive construction of concepts of forgiveness, sin, guilt, shame and reconciliation. Forgiveness is one area where the pastoral power to hold '... a knowledge of the conscience and the ability to direct it' is clearly evident (Foucault 1994: 333). This framework of pastoral power 
became important in exploring research participants' own understandings of their pastoral role and identity.

Foucault (1980: 131-133) argues that the capacity to construct 'truths' is often defined by the political, institutional and cultural context in which discourses are enabled. Due to the existence of specific institutional discourses, the management of abuse in Christian institutions is one of the explicit cases where forgiveness has been directly employed as a strategy to address the identity construction of both victim/survivors as well as perpetrators (cf. Jenkins Hall and Joy 2002; Parkinson 2003). Perhaps unlike the occurrence of abuse in broader society, the Church has often demonstrated a vested interest in forgiving and retaining the services of PICIs who abuse children (cf. O'Leary 2003). This is in stark contrast to growing public awareness and outrage at the sexual abuse of children by trusted PICIs who have taken advantage of their governing powers over their flock to commit crimes of abuse and avoid detection and prosecution under violent offender laws (McSherry and Keyser 2009). The management of abuse within a Christian institutional environment has often come at the cost of silencing, marginalising and confining the ability of victim/survivors to construct healthy discourses of self (cf. Dale and Alpert 2007). It is worth bearing in mind that victim/survivors' voices and rights have been hard-fought even in secular institutions (Cossins 2008; Daly 2011; Julich 2006; Smart 1989). For the Christian institution, however, management of abuse allegations has all too often meant relying on discourses of forgiveness which privilege the needs of the Church and of perpetrators and rationalise this privilege within a discourse of forgiveness, while simultaneously rendering the voices of victim/survivors and the harms done to them invisible to the outside world (cf. O'Leary 2003). The participants of this study recognised that circumstances where pastoral power was unbalanced and unchecked protected abusive relationships, which become internalised in a mode of pastoral governance built around the discourse of forgiveness.

There is evidence, however, that Christian institutions are confronted with particular difficulties when attempting to engage the victim/survivor in the creation of an autonomous self through appealing to institutional values (cf. Terry and Ackerman 2008). In so far as Foucault (1984: 336) understands the subject as revealed through 'types of understanding, forms of normativity, and modes of relation to oneself and others', forgiveness can be understood to form a condition in which the subject presents as viable to the other. Just as confession requires the presence of another, so forgiveness requires an 'other' (Taylor 2009: 168-169). Were there not an 'other', forgiveness would not be necessary and could not be utilised as a discourse of the self. In this particular context, this 'other', for victim/survivors, may be a person in a Christian institution as bearer of spiritual influence and the perpetrator of harm; a Church congregation through the giving of a testimony of self which includes forgiveness; or God.

For victim/survivors of abuse by PICIs, their corporeal experiences of abuse have often been denied or minimised within Christian institutions by discourses of forgiveness (cf. Franz 2002). Similarly, in criminal justice, victim/survivors' corporeal realities have often been denied or reshaped by legal discourse that have limited their ability to voice their experiences (Daly 2011; Smart 1989). Rejection of victim/survivors' corporeal realities by Christian institutional discourses has been most evident where forgiveness does not enable victim/survivors to construct their stories in meaningful ways. For example, engaging in public story telling of self allows victim/survivors the opportunity to gain from and provide identity narratives that other victim/survivors may appeal to (cf. Burke Drauker and Martsolf 2008). It should be noted, however, that not all victim/survivors will wish to publicly construct their stories and should not be forced to by others disclosing the abuse on their behalf (Morrison 2005: 25-26). The silencing of discourses of self through rejecting story telling is a dismissal of a norm by which survival can be openly celebrated as valuable in and of itself. As such, appeals to virtues such as courage, resilience and determination in the face of abuse, pain and deep spiritual conflict become subsumed by discourses of the value of forgiveness as life-giving and the primary 
concept of self. Again, facilitating ways in which victim/survivors can tell their stories with authority and reclaim dignity and power through such processes is not an exclusively unique issue for Churches (Cossins 2008; Daly 2011; Julich 2006; Smart 1989).

Perhaps the most significant issue in the deployment of forgiveness discourses is the development of a means by which victim/survivors have ultimate autonomy over their stories of abuse and are able to engage in constructing their discourses of self which are valuable to them and enhance their agency. Forgiveness may well be one of these mechanisms but some discourses of forgiveness are more productive to this end. However, because language is malleable, survivors may have an opportunity to access forgiveness discourse in ways which do not reject it entirely but shape it to reflect and generate their own realities and their own identities and to participate in the identities of others - remembering that forgiveness is relational.

\section{The study}

This paper emerged from 15 semi-structured interviews with PICIs from several denominations across New South Wales, Queensland and the Australian Capital Territory. Interviews were conducted at the location of each participant's choice and lasted between 45 minutes and three hours. One interview was conducted over two sessions at the participant's request. Some interviews were conducted by telephone due to travel restrictions. Each participant signed a consent form to participate and was assured every effort would be made to protect their identity. Each interview was transcribed and coded thematically to identify dominant themes. NVIVO was used to manage interview data. This study particularly targeted individuals who had engaged with the management of abuse by PICIs in their professional or personal ministries and were pro-active in supporting victim/survivors.

The specific intent of this project was neither to enhance divisions between denominations nor to encourage the scapegoating of the issues by blaming other denominations as solely responsible for the crises that have faced Christian institutions. As such, the original project was conducted without indicators of the Christian tradition or denomination from which participants spoke. Several reviewers of the project stated, however, that they felt it was necessary to identify each participant's theological position. In response, three broad terms have been developed to give some indication of this. The term traditional indicates strong hierarchical structures and largely conservative theology. The term non-traditional has been utilised to include all protestant denominations that do not conform to the constraints of the traditional category. The term Pentecostal is used to identify those who self-identified as Pentecostal and who had a particular theological emphasis on the role of the Holy Spirit in spiritual life and governance. Research participants rarely drew on identifiers of this type in expressing their understanding of their role and the power they utilised in performing their roles within their Christian institution. It is the function of power in the occurrence and management of abuse in Christian institutions that will now be explored.

\section{Power and Church leadership}

Over a decade ago, Dallavale (1996: 1) identified power as the central issue to be confronted in the management of abuse by PICIs:

Studies of the problem of clergy sexual abuse tell us that such abuse is primarily about power and trust, not sexuality. Given this, those of us who are concerned about sexual abuse - victims, church members, abusers - might want to ask ourselves about the models of power we practice.

Dallavale's (1996: 1) challenge continues to be of central relevance to understanding sexual abuse by PICIs and its management. In any organisation, the institutional culture is influenced 
by managerial values and those in leadership positions (cf. Wallace, Hunt and Richards 1999). For Christian institutions, this responsibility is largely that of ordained clergy in hierarchical structures. Other forms of leadership can often be influential in processes which define an individual Church ethos, however. Participants in this study displayed varying levels of understanding of their own use of power. This included identifying their ability to exercise power because of the institutional and structural nature of their positions and also in their personal power as individuals in ministry. Only one participant denied they had any level of power as an ordained minister.

At times, the terms power and authority were used inter-changeably by research participants. Utilising Foucault's conceptual framework (1976: 92-96, 1994: 326-345), PICIs do not possess power as individuals, but, rather, their ability to exercise power is produced through discourse about their status, role and social/religious function; pastoral power, like other forms of power, is relational and discursive. Hence, understanding the role of power for PICIs is directly related to understanding knowledges produced about and through them (Foucault 1994: 333).

Research participants had different levels of recognition of the role of power or authority in their ministry, the source of this power and its exercise. Malaki (non-traditional) provides an articulation of this, saying:

I think there's two lines of authority. One is you get authority from, from those who appoint you but the other authority is, is the authority a person carries in themselves, in their own character, their own integrity, their own grace or confidence or whatever. ... So my authority comes from the Directors of [Institution A] and um, and then because of our theological and philosophical positions as Christians. Then the directors would say they got their authority from scripture and through that from God. So um, what I'm saying is that my authority derives from human choice and I believe from God as well.

Malaki views his own power as coming from different discursive constructions of himself as a subject. The first series of discourses he draws on sees a transferring of leadership that is clearly about identifying subjects through a narrative of conferred authority. Foucault's (1994: 333) view of pastoral power and of governmentality within the hierarchical construct of many churches helps to enable an understanding of senior leaders' responsibility for the spiritual guidance to salvation of more junior leaders (cf. Foucault 1991). This conferring of authority is made visible through interactions between leaders as well as the services and rituals they perform and the internalisation and performativity of this discursive authority by individual subjects in institutional settings; in Malaki's case, through the Directors of his Christian organisation. Part of Malaki's subjectivity as a bearer of authority becomes visible only through the performance of a particular relationship of governance by other Christians who also hold authority. The very signifier of 'Christian' as a 'theological and philosophical position' is pivotal in Malaki's claim to authority through others. In Malaki's perception, authority, as conferred by others, is derived from biblical discourse and a discursive construction of God as the bearer and transmitter of authority (cf. Bernauer 2005). This is evidentially a theocratic setting whereby God is the figurehead of churches and their institutions and considered to be the ultimate source from which authority is conferred.

The second form of authority Malaki constructs comes from his personal presentation and understanding of self (cf. Butler 2005). This authority relies on engagement with others and their construction of him as a subject who holds qualities consistent with an individual to whom they are willing to accept leadership. In addition to this, external subjects must observe that Malaki possess characteristics worth emulating in their own lives for his authority to be legitimate. This type of authority requires being recognised as a subject by others and maintaining this recognition through the performance of self (cf. Butler 2005). This 
performance of self happens in relationship with others, including superiors and those for whom PICIs have responsibility for the directing of their souls to salvation (Foucault 1994: 333). In short, the enacted positive character of the subject becomes a form of authority for others to look to. Particular to pastoral power is the nature of this leadership as being sacrificial, which requires not only knowledge of those for whom the sacrifice is required but a knowledge of self which is sufficient to make this sacrifice (Foucault 1994: 333). Hence we see, in Malaki's positioning of his authority, that governance of the self and the manifestation of one's own character become essential in governance of others (Foucault 1991: 91).

This theme of mixing personal characteristics and institutional position as sources of power was common amongst research participants' responses. However, a majority of participants were most clearly able to recognise they had certain types of power to govern because of the institutional affirmation of their position of leadership. As Church leaders, they understand power is derived structurally within the denominations they served. Mediating and managing this power was of great concern for some participants. When asked what types of power he thought he exercised in people's lives, John (non-traditional) responds with:

Sometimes really scary power, ah, people will take what I say and without any contextualisation, go with it. ... I try to make sure that what I say is true and try and make sure that those I'm with use their heads, that it's not blind faith, it's not blind following. I make sure they know I'm not infallible, that I need support, I need to have people around me that I can talk to, that I can share thoughts so that they can help focus and funnel, so that I keep right.

In John's response, we can see Foucault's (1976: 27-28) power/knowledge nexus employed as praxis. John is clear that his exercising of pastoral power though the construction of discourse and teaching is open to criticism. He is also aware that those who participate in his congregation share the responsibility of generating knowledge. The contribution of the congregation as thinking individuals is valuable to John in his praxis and assumes the ability of others to act in conformity or resistance to such exercise of power through discursive constructions (Gordon 1991: 5). For John, the potential of discourses of resistance emerging from his congregation serves as a means of ensuring his own position not only represents 'truth' but also his teaching and leadership are transparent and open to competing discourses. For John, that his power, exercised through truth production, is something which may be used constructively for the benefit of others remains clearly relational and reproduces itself through engagement with others. Essential in this, however, is John's recognition of his enacting power in truth production. John offers a truth to his congregation but in turn he relies on a critique from them and knowledge of himself as a subject to provide checks and balances to his production of truth.

In this way, John provides his own discourse of resistance to what Benkert and Doyle (2009) have called 'religious duress'. Religious duress occurs when institutional structures so value the position and construction of PICIs that they are not able to be challenged. The consequence of this is PICIs are able to exercise a form of psychological and spiritual power over individuals within their congregations that results in silencing those voices which challenge and confront. This position has allowed PICIs who perpetrate abuse to be sustained and protected by church institutions as 'men of God' and has left victim/survivors in a position of exclusion (cf. Benkert and Doyle 2009). For John, we can see an understanding of power as being both repressive and productive (cf. Foucault 1994: 167). John takes the repressive power of religious duress and deliberately incorporates a form of critique and resistance in his own personal exercise of power in producing subjects within his congregation.

John also illustrates a form of self-governance in that, prior to communicating his own infallibility and need for support, he must first recognise these in himself and incorporate them into his concept as a subject. This reflexive discourse and examination of self, this disclosure of 
fallibility and need, is important in understanding the use of confession as a technology of the self within Christian tradition (Foucault 1976: 59-64). For John, his confession is a means of constructing himself publicly as leader and as a Christian man. John's construction of self requires engagement with others to perform his leadership role to a standard that remains consistent with his personal objective to 'keep right'. The means of doing this is to ensure there are others in his life exercising pastoral power sufficient to have an intimate knowledge of his mind and soul through confessions of self.

Similarly to John, Esther (non-traditional) recognises a struggle with her pastoral power saying:

... So the whole issue of having power, umm, so I struggled with it for a long time. I've come to be more comfortable with it in the last few years because I see okay, I do have this power but do I wield it for good or evil?

In the understanding of both John and Esther, power is accompanied by the responsibility of ensuring the ongoing legitimacy of their own operation of power and constructions of themselves as leaders. Here we see an awareness in Esther that power can be both repressive and productive and that she has responsibility to govern the lives of others in particular ways (Foucault 1994: 333). For example, Esther seriously considers the impact of the use of her power for 'good' or for 'evil', both concepts which directly imply an impact and an assessment of self as an ethical subject. What is interesting about Esther's comment is that it demonstrates a struggle, taken over 'a long time', to integrate an understanding of one's self as powerful into one's governance of others. For research participants, there is a concern they exercise power to ensure the ongoing spiritual wellbeing and benefit of their congregations and individuals with whom they hold a form of intimate relationship based on personal disclosure (Foucault 1994: 333). This begins, however, with understanding and embracing a concept and performance of self that accommodates such a discourse. For John, however, this relationship with self and others is clearly articulated as mutual, where he also confesses he is fallible and in need of the spiritual direction and support of others.

John (non-traditional) goes on to establish a particular understanding of himself as a spiritual leader who is fallible and in need of accountability. He sees this as an imperative part of forming his identity as a leader, both on a personal and public level. John recognises there is resistance to this model of leadership:

Sometimes they don't want that, they just want a figurehead that they can blindly follow. Which, I guess, is where I try and use the authority as a position to turn them towards the authority because of relationship.

For John, it is ideal that authority is exercised through a relationship that is based upon his knowledge of people's souls and minds including other's knowledge of him as a subject. It is other's knowledge of him that John draws on to exercise power in reshaping knowledge. This understanding conveys an intimacy between PICIs and those they govern that seeks not to manipulate and control but to benefit them through encouraging independence in thought and autonomy. Esther (non-traditional) discusses a similar situation in her ministry:

I'm there to resource the people; I'm there to support them in their ministry. Um, my experience was 'no you are the minister, you need to lead us, you need to tell us what to do and you need to do most of it'.

For both John and Esther, their own understanding of their ministry and the exercise of power at times directly conflicts with what others expect of them. They now see themselves as agents exercising their pastoral power to challenge this construction of Christian leadership. Both Esther and John seek to construct new 'truths' about what their role is as a leader in their 
Christian institutions. In doing so, John and Esther rely on an ability to create a particular form of intimacy with their subjects which then enables them to direct their conscience (Foucault 1994: 333). In seeing her role as one of equipping and resourcing the community, Esther in particular demonstrates that this relationship is one where the greater good of those who are subject to governance is the ultimate consideration. Foucault (1994: 333) points out that such is the nature of the exercise of pastoral power. This has not always been the exercise of power demonstrated by those in positions of leadership within Christian institutions.

Many participants acknowledge a model of Church leadership that imbues leaders with ultimate, unquestionable authority was dangerous and facilitated abusive environments. Rebekah (non-traditional) describes this:

... because a lot of ministers want to say that they speak the word of God and must be listened to, I mean that's still prevalent even though I, you know, I wouldn't hold to that and I don't actually think our polity hold to that, um, some ministers really still live out of the old model. So in the minds of the congregation, they are better than them because they're people of God. So they sort of put them up on a pedestal ... but again that's manipulation, that's not appropriate behaviour.

Once again we can see that particularly ordained PICIs, as knowledge producers, can maintain control over what constitutes the 'word of God' and that this position is being weakened by what Rebekah understands to be a new model of Church leadership. Rebekah suggests this monopoly on truth production by Church leaders is changing to a more collaborative approach. This shift is essential in undermining a key attitude which has supported perpetrators of abuse in Christian institutions and silenced victim/survivors. Doyle (2006: 189) argues traditional discourses of clericalism isolate Church leaders in power structures and thus enable sexual abuse. Doyle (2006: 190) sees clericalism as a 'radical misunderstanding of the place of clerics', going on to qualify this by saying:

This pejorative 'ism' is grounded in the erroneous belief that clerics constitute an elite group and, because of their powers as sacramental ministers, they are superior to the laity. These spiritual powers have historically led to a variety of social privileges which in turn have regularly resulted in different levels of corruption.

Arguably the results of this model of power, when applied to abuse by PICIs, have meant that constructions of forgiveness have been utilised to protect the institution; shield abusing PICIs; isolate and disempower victim/survivors; control the conveyance of survivor stories; and, ultimately, create spiritually and emotionally abusive environments (cf. Franz 2002).

\section{Forgiveness as freedom power and identity}

Given the centrality of forgiveness to Christian doctrine and practice, it is not surprising that research participants saw forgiveness as an important part of managing abuse by PICIs (cf. De Smet 2007). This view is supported in literature which recognises how forgiveness has been utilised in Christian institutions as a strategy for responding to abuse by PICIs (cf. Franz 2002; Keenan 2012; Macaskill 2005). This literature often recognises discourses of forgiveness have been defined in such a way as to be disempowering for victim/survivors and to narrow their ability to speak about their abuse by PICIs, as well as to maintain the position of the individual perpetrator as an authority figure. Such models of forgiveness have justified moving PICIs between appointments, without disclosure of their history of abusing the young and the vulnerable (cf. Isley et al. 2008). In this light, forgiveness is a discourse that makes perpetrators and victim/survivors visible in certain ways. This model of forgiveness also carries with it an 
ethical conceptualisation that may be used to perpetuate the possibility of abuse through protecting the identity of offenders as 'men of God'. Further to this, it silences and marginalises victims by placing the burdens of forgiveness on them and tying these directly to their visibility as an ethical subject.

Some research participants clearly recognised this history of manipulating forgiveness. They identified this manipulation as a further abuse of power inconsistent with a construct of forgiveness that was beneficial for victim/survivors of Church abuse by PICIs. This meant forgiveness was most often defined within themes of freedom. James (traditional) argues that:

To forgive um, is to allow a situation or a person to move on and it's to acknowledge that something happened, which has left a real impression or mark on a life, and by that career, family, but, but you are not held captive by it any more. ... Forgiveness is liberation, it's freedom um, and being able to let go and move on.

James defines forgiveness by its ability to liberate victim/survivors of harm from at least some of the consequences of that harm. For James, forgiveness is an act which comes from the agency of the victim/survivor. It is, in part, through exercising this agency that a victim is seen as constructing an identity that moves beyond powerlessness as a result of abuse to one as a survivor. In the perception of research participants, forgiveness is understood as a discourse of resistance controlled by victim/survivors, rather than by others (cf. Foucault 1977). From this perspective, forgiveness should not be demanded as the only suitable response but also one that can be appropriated by victim/survivors for themselves in the process of a journey rather than a single event (Jenkins, Hall and Joy 2002: 35). This model of forgiveness emphasises the choice and exercise of power that victim/survivors have to gain when they forgive as a means of liberating themselves.

For many participants, this liberty was characterised specifically in terms of moving beyond perpetrators' ability to wield power over their victim/survivors. For Rebekah (non-traditional):

Until ... I can forgive that person they still have power over me. ... I really see hatred of someone um, as a negative thing, that I'm using my energy in a negative way and so until I can just accept that this has happened and forgive them, I might not like them, I might not want to have any contact with them or anything but ... it means that you can move on.

Participants argued that, consistent with literature, liberation from negative emotions such as hatred, resentment, fear and the desire for revenge are the primary benefits of forgiveness (Worthington, Sharp and Lerner 2006: 33). Holly (non-traditional) further describes the significance for survivors in neutralising perpetrators' power:

I think it [forgiveness] is really vital because how can you have freedom? Um, I often say to clients, it's a bit like the puppet on the string, you know, and if the perpetrator walked into this room he would play you, he would have your emotions in chaos because, you know, you haven't cut those strings and I think cutting those strings is like forgiveness ... and if they can forgive then they can experience life for themselves ...

It is clear these research participants see forgiveness as an act of power enabling victim/survivors to construct their identities and reframe perpetrators as no longer able to manipulate or control them. To forgive is to exercise autonomy and exorcise the perpetrator from their internalisation of their subjectivity: they are no longer victims, but empowered survivors. This is a form of identity change where victim/survivors appeal to new discourses to 
present a 'self' to be recognised by others (cf. Butler 1997, 2004, 2005). Butler's (2006: 66) explanation of the self as non-static and constructed in narrative lends insight to the ways in which victim/survivors can construct and present fluid identities. Such narratives of self are initiated at a particular time, enacted through articulation in language, and linked to other narratives of self. In this transformative process, forgiveness may be constructed as a part of an ongoing safety plan for victim/survivors because it begins in remembering, acknowledging the harm done by the abuse and moves to relinquishing negative feelings and reinventing the self as no longer damaged (Jenkins, Hall and Joy 2002: 39). Forgiveness is understood to be a shift in discourses of self that, for many participants, identifies it as a means of constructing survivor identity rather than a victim mentality forever waiting to be re-victimised. This identity is seen as no longer powerless to perpetrators but empowered to 'experience life for themselves' (Holly, non-traditional), or in a process of empowerment which emphasises choice.

Malaki (non-traditional) articulated similar themes to Dinah (non-traditional), arguing forgiveness was an act of volition not emotion:

... if someone offends against one of those rules against me, that gives me a clear right as a member of the human race to say 'You've, you've broken the law here and, and so I'm going to have to forgive you. I don't want to forgive you, I don't feel like forgiving you but I will as an act of the will'. So I think forgiveness is not actually a feeling, it's an act of the will, it's a choice. And umm, and ... it's a posture that we have to maintain because on any week, if I start remembering what this person did that was abusing me in that umm, psychological way when I was young, if I start thinking about it, I can start, I can actually descend back into that hate and I can actually start re-living it all.

Malaki identifies forgiveness as an ongoing choice, as an ongoing engagement with identity formation and as a means of asserting agency over negative emotions. Malaki clearly demonstrates how constructing a narrative of himself as forgiving, that making this identity claim, is a fluid process which he actively engages with to re-order or reconstruct his emotional identity (Butler 2005: 66).

Butler's (2005: 66) framework for understanding of the narrative presentation of self over time provides insight into Malaki's process of understanding and representing self:

I begin a story about myself, and I begin somewhere, marking a time, trying to begin a sequence, offering perhaps, causal links or perhaps narrative structure. I narrate and I bind myself as I narrate, give an account of myself to another in the form of a story that might well work to summarise how and why I am.

For Butler (2005: 66), this narrating of self is a performative process because the ' $\mathrm{I}$ ' is constituted and reconstituted in the narrating of self. As for Malaki, the construction of self as forgiving is a story told and retold, just as the choice to forgive is repeated and performed again and again. In a sense, this telling and retelling of a narrative of forgiveness is experienced as therapeutic by participants because the self evolves away from negative emotions to positive liberating emotions and actions (Oliner 2009: 381).

This also demonstrates that forgiveness is a part of an ethical construction of self and of others (Butler 2005: 42; see also Foucault 1984). In Butler's (2005: 42) analysis, the subject's search to identify the self by the available norms is necessarily temporal and doomed to failure. Once the self is recognised by the subject, identity is destabilised. This destabilising is essential to the pursuit of identifying the self and of expecting others to self-identify. Within the discursive context of a theological environment, in order to identify the promises of forgiveness to liberate and heal the individual, victim/survivors of abuse by Church leaders must be willing to sacrifice 
something of their own understanding of themselves, to seek to identify by the promises of forgiveness to liberate and heal. This transition is a dangerous one for the victim/survivor to undertake, precisely because it happens in relationships with others and is reliant on a spiritual authority for the transmission of the discourse by which life and self will, henceforth, be defined.

\section{Concluding thoughts}

The research participants in this study were all leaders sympathetic to the case that Christian institutions need to take responsibility for abuses of power by its leaders. They understood that there is a role for PICIs to mange not only outcomes, but as producers of truth, to manage and guide the ways in which subjects are governed, healed and have their identity recognised. Research participants did this, however, within particular understandings of themselves as God's subjects with the authority conferred upon their role as PICIs to govern their 'flock' in terms of a discourse of pastoralism - one form of governmentality to which Foucault (1979) drew our attention as important to the emergence of bio-power. Whereas, in criminal justice systems, the production of truth allegedly seeks to rely on evidence and, to some degree, character, in Christian institutional management of abuse allegations, there has been a focus on governing individuals through their soul. This level of governance deliberately assumes responsibility for identity construction of victim/survivors as well as perpetrators and other PICIs. This is evident in the use of forgiveness as a narrative of self as well as a discipline through which the subject becomes visible as forgiving or forgiven. This governance is intrinsically relational and, on some levels, assumes an ongoing relationship between victimabuser whereby individual identity will continue to be constructed in relation to the Church, Church leaders and governing discourses.

For the participants in this project, their understandings of their own exercise of pastoral power as PICIs leave room for an ethical engagement with forgiveness discourses that value the stories and empowerment of victim/survivors. This engagement needs to challenge abusive practices of pastoral power and also facilitate victim/survivor participation in creating discourses of forgiveness. Such discourses will be focussed on the needs of victim/survivors rather than perpetrators of harm. Whilst there is a history of Christian institutions manipulating forgiveness to protect perpetrators of abuse within institutions, there is also a history of participating in a politics of forgiveness that values justice (cf. Appleby 2000). It is only through ongoing engagement with victim/survivors, listening on their experiences, valuing their voices and facilitating their contribution to a different ethos of forgiveness that justice and trust will be restored to Christian institutions' management of abuse by personnel within those institutions. Inherent in this is the capacity for the voices of pro-active PICIs to be heard and translated into public discourses which facilitate their identity in ways other PICIs can appeal to in understanding their role. Through their representations of their pastoral power and forgiveness, research participants (all whom were sympathetic to accepting responsibility for Church abuse) demonstrated a concern to present their self in ways which value power sharing, mutual truth production and discourses of resistance. In these voices, there is a 'reaching for hope' (John, non-traditional) that the deployment of forgiveness discourses can be constructive rather than destructive. This discursive strategy is also liberating for Christian institutions as it strikes to the heart of forgiveness and means that the Church does not have to always be defined by its past (Onliner 2009: 382).

Correspondence: Dr Jodi Death, Lecturer, School of Justice, Faculty of Law, Queensland University of Technology, Brisbane. Email: jodi.death@qut.edu.au.

1 The term victim/survivors is used in this article in line with feminisms recognition that victim is a limiting term that does not accurately describe the feelings of those who have experiences gendered violence. This term further recognises that experiences of gendered violence and recovery from these experiences is a dynamic process, 


\section{References}

Appleby RS (2000) The Ambivalence of the Sacred: Religion, Violence, and Reconciliation. Lanham: Rowman \& Littlefield Publishers Inc.

Balboni J (2011) Clergy Sexual Abuse Litigation: Survivors Seeking Justice. Boulder: First Forum Press.

Benkert M and Doyle TP (2009) Clericalism, Religious Duress and its Psychological Impact on Victims of Clergy Sexual Abuse. Pastoral Psychology 58(3): 223-238.

Bernauer J (2005) Confessions of the soul: Foucault and theological culture. Philosophy and Social Criticism 31(5-6): 557-572.

Brownmiller S (1975) Against Our Will: Men, Women and Rape. Harmonsworth: Penguin Books.

Burke Drauker C and Martsolf DS (2008) Storying childhood sexual abuse. Qualitative Health Research 18(8): 1034-1048.

Butler J (1997) Excitable Speech: A Politics of the Performative. New York: Routledge.

Butler J (2004) Undoing Gender. New York: Routledge.

Butler J (2005) Giving an Account of Oneself. New York: Fordham University Press.

Butler J (2006) Precarious Life: The Powers of Mourning and Violence. London: Verso.

Cannon A (2012) Clergy child abuse action victims hail inquiry. Geelong Advertiser 18 April: 1.

Carrette J (1999) Prologue: A confession of the flesh. In Carrette J (ed) Religion and Culture: Michel Foucault. New York: Routledge: 1-48.

Carrington C and Carmody M (2000) Reventing sexual violence? The Australian New Zealand Journal of Criminology 33(3): 341-346.

Carrington K and Watson P (1996) Policing sexual violence: Feminism, criminal justice and governmentality. International Journal of Sociology of the Law 24: 253-272

Carmody M (1997) Submerged voices: Co-ordinators of sexual assault services speak of their experiences. Affilia 12(4): 452-470.

Chambers G and Millar A (1987) Proving sexual assault: Prosecuting the offender or persecuting the victim? In Carlen P and Worrel A (eds) Gender, Crime and Justice. Milton Keynes: Open University: 58-80.

Cossins A (2008) Restorative justice and child sex offences: The theory and practice. British Journal of Criminology 48: 359-378.

Cullen S (2012) Gillard launches royal commission into child abuse. ABC News (online). Available at http://www.abc.net.au/news/2012-11-12/gillard-launches-royal-commissioninto-child-abuse/4367364 (accessed 7 November 2012).

Dallavale NA (1996) Power and gender and religion. The ITSI Sun 2(1): 1-2.

Daly K (2011) Conventional and innovative justice responses to sexual violence. ASSCA Issues No 12. Melbourne: Australian institute of Family Studies.

Dale KA and Alpert JL (2007) Hiding behind the cloth: Child sexual abuse and the Catholic Church. Journal of Child Sexual Abuse 16(3): 59-74.

Death J ( 2012) Lessons on sin and forgiveness: A crisis in the Roman Catholic Church. In Ata A (ed) Catholics and Catholicism in Contemporary Australia. Melbourne: David Lovell Publishing: 299-306.

Department for Women (1996) Heroines of Fortitude: The Experiences of Women in Court as Victims of Sexual Assault. Sydney: NSW Government.

Department of Justice and Equality (2009) Report by Commission of Investigation into Catholic Archdiocese of Dublin (online). Available at http://www.justice.ie/en/JELR/Pages/PB09000504 (accessed 12 September 2012). 
De Smet A (2007) Forgiveness: Making some connections between theology and psychology, preaching and pastoral practice. The Expository Times 199(3): 116- 119.

Doyle TP (2006) Clericalism: Enabler of clergy sexual abuse. Pastoral Psychology 54(1):189-213.

Esteal P (1994) Voices of the Survivors: Powerful and Moving Stories from Survivors of Sexual Assault. North Melbourne: Spinifex Press.

Foucault M (1976) The Will to Knowledge: The History of Sexuality, Volume 1. London: Penguin Group.

Foucault M (1977) Discipline and Punish: The Brith of the Prison. Michigan: Knopf Doubleday Publishing Group.

Foucault M (1979) Pastoral power and political reason. In Carrette JR (1999) (ed) Religion and Culture: Michel Foucault. New York: Routledge: 135-152.

Foucault M (1980) Power/Knowledge: Selected Interviews and Other Writings 1972-1977. London: Harvester Press.

Foucault M (1984) Preface: The History of Sexuality, Volume 2. In Rabinow P (ed) The Foucault Reader. New York: Pantheon Books: 333-339.

Foucault M (1985) The Use of Pleasure: The History of Sexuality, Volume 2. London: Penguin Books.

Foucault M (1986) The Care of Self: The History of Sexuality, Volume 3. London: Penguin Books.

Foucault M (1991) Governmentality. In Burchell G, Gordon C and Miller P (eds) The Foucault Effect: Studies in Governmentality. Hertfordshire: Harvester Wheatsheaf: 87-104.

Foucault M (1994) Sex, power and the politics of identity. In Rabinow P (ed) Michel Foucault: Ethics, Subjectivity and Truth. New York: The New Press: 163-174.

Franz T (2002) Power, patriarchy and sexual abuse in churches of Christian denomination. Traumatology 8(1): 4- 17.

Gadon L, Johnstone L and Cooke D (2006) Situational variables and institutional violence: A systemic review of literature. Clinical Psychology Review 26: 515-534.

Gordon C (1991) Governmental rationality: An introduction. In Burchell G, Gordon C and Miller P (eds) The Foucault Effect: Studies in Governmentality. Hertfordshire: Harvester Wheatsheaf: $1-52$.

Isley PJ, Isley P, Freiburger J and McMakin R (2008) In their own voices: A qualitative study of men abused as children by Catholic clergy. Journal of Child Sexual Abuse 17(3): 201-205.

Jenkins $M$ and Iara M (2012) Vic government under fire over church inquiry. AAP (online). Available at http://www.couriermail.com.au/ipad/vic-govt-under-fire-over-churchinquiry/story-fn6ck4a4-1226330565428 (accessed 12 September 2012).

Jenkins A, Hall R and Joy M (2002) Forgiveness and child sexual abuse: A matrix of meanings. The International Journal of Narrative Therapy and Community Work 1: 35-51.

John Jay College of Criminal Justice (2004) The Nature and Scope of the Problem of Sexual Abuse of Minors by Catholic Priests and Deacons in the United States (online). Available at http://www.jjay.cuny.edu/churchstudy/main.asp (accessed 12 September 2012).

Julich S (2006) Views of justice among survivors of historical child sexual abuse: Implications for restorative justice in New Zealand. Theoretical Criminology 10(1): 125-138.

Keenan M (2012) Child Sexual Abuse and the Catholic Church: Gender, Power and Organizational Culture. Oxford: Oxford University Press.

Macaskill A (2005) Defining forgiveness: Christian clergy and general population perspectives. Journal of Personality 73(5): 1237-1266.

McSherry B and Keyzer P (2009) Sex Offenders and Preventative Detention: Politics, Policy and Practice. Sydney: The Federation Press. 
Morrison Z (2005) Reporting the Abuse of Children and Young People and Responding to Adult Sexual Assault: A Study into the Attitudes and Behaviours of Clergy and Church-Workers in the Anglican Diocese of Adelaide When Dealing with the Abuse of Children and Sexual Assault of Adults (online). Available at www.ministry-development.org/pdfs/morrison_report_full.pdf (accessed 27 February 2007).

O'Leary P (2003) The Church, confession, forgiveness and male sexual abuse. In White C (ed) Responding to Violence: A Collection of Papers Relating to Child Sexual Abuse and Violence in Intimate Relationships. Adelaide: Dulwich centre Publications: 8-13.

Oliner SP (2009) Altruism, apology, forgiveness and reconciliation as public sociology. In Vincent J (ed) Handbook of Public Sociology. Lanham: Rowman \& Littlefield Publishers: 375390.

Parkinson P (2003) Child Abuse and the Churches: Understanding the Issues, 2nd edn. Sydney South: Aquila Press.

Robertson G (2010) The Case of the Pope: Vatican Accountability for Human Rights Abuses. London: Penguin Books.

Rowntree M (2010) Living life with grace is my revenge: Situating survivor knowledge about sexual violence. Qualitative Social Work 9(4): 447-460.

Shults FL and Sandgate S (2003) The Faces of Forgiveness: Searching for Wholeness and Salvation. Grand Rapids: Baker Academic.

Smart C (1995) Law, Crime and Sexuality: Essays in Feminism. Thousand Oaks: Sage Publications.

Smart C (1989) Feminism and the Power of Law. Routledge: London.

Taylor C (2009) The Culture of Confession from Augustine to Foucault: A Genealogy of the 'Confessing Animal'. New York: Taylor and Francis.

Terry KJ and Ackerman A (2008) Child sexual abuse in the Catholic Church: How situational crime prevention can help. Criminal Justice and Behaviour 35(5): 643-657.

Walklate $S$ (2008) What is to be done about violence against women?: Gender, violence, cosmopolitism and the law. British Journal of Criminology 48: 39-54.

Walklate S (2012) Courting compassion: Victims, policy and the question of justice. The Howard Journal 51(2): 109-121.

Wallace J, Hunt J and Richards C (1999) The relationship between organisational culture, organisational climate and managerial values. The International Journal of Public Sector Management 12(7): 548-564.

White MD and Terry KJ (2008) Child Sexual abuse in the Catholic Church: Revisiting the rotten apples explanation. Criminal Justice and Behaviour 35(5): 658-678.

Worthington EL, Sharp CB and Lerner A (2006) Interpersonal forgiveness as an example of loving one's enemies. Journal of Psychology and Theology 34(1): 32-42.

Young A (1998) The waste land of law, the wordless song of the rape victim. Melbourne University Law Review 22(2): 442-465. 